\title{
FEM Analysis of Stress Distribution in the Hermetic Harmonic Drive Flexspline
}

\author{
J. Pacana, ${ }^{1}$ W. Witkowski, ${ }^{2}$ and J. Mucha $^{3}$ \\ Rzeszów University of Technology, Rzeszów, Poland \\ ${ }^{1}$ pacanaj@prz.edu.pl \\ 2 wwitkowski@prz.edu.pl \\ 3 j_mucha@prz.edu.pl
}

УДК 539.4

\section{Скінченноелементний аналіз розподілу напружень у герметичному гармонічному редукторі 3 гнучким сплайном}

\author{
Я. Пацана, В. Вітковскі, Я. Муха \\ Жешувський технологічний університет, Жешув, Польща
}

Виконано чисельний розрахунок напружень у гнучкому сплайні зубчатої передачі гармонічного (хвильового) редуктора. Зубчате кільие у гнучкому сплайні через складну геометрію моделювалось у вигляді кільия. Висоту кільия приймали з урахуванням напруженості в зубиях. Для вивчення впливу різних типів хвильових генераторів на розподіл напружень у гнучкому сплайні розглядали моделі з двома та чотирма роликами, ексиентриком або диском. Розрахунок напружень виконували для двох варіантів: без обертального моменту та з обертальним моментом, що відповідає реальним умовам роботи герметичного гармонічного редуктора.

Ключові слова: герметичний гармонічний (хвильовий) редуктор, розподіл напружень, скінченноелементний аналіз.

Introduction. Production automation requires the use of high-quality propulsion systems for industrial robots with high reliability, as well as adequate rigidity and minimum weight of housing and framework of manipulators [1]. A power transmission system of manipulators and industrial robots should have several prominent features, one of these being its high total gear ratio, which is critical for minimizing its size and weight [2]. Therefore, application of harmonic drives in robots transmission systems is very instrumental to achieve this goal. For this type of systems, a high stiffness during the loading process is required from the propulsion system components and, especially, the flexspline teeth rim [3]. The operation of a propulsion system with a harmonic drive is controlled by the work kinematic of the latter [4].

In the strength analysis of harmonic drive, determination of stress distribution in it is an extremely important issue: it is mandatory for the optimal designing of propulsion systems used in industrial robots or space industry [5]. During the modeling in CAD systems, a critical issue is the accuracy of tooth side mapping [6]. Similar to the classical gears, the shape of flexspline teeth rim controls the gear operation conditions, especially under the oscillation conditions [7-9]. A number of research papers, including those mentioned earlier, concern the vibration analysis [2-5, 10-12], new models for more accurate characterization of propulsion system, and the tooth profile accuracy effect on the gear teeth mapping [13]. Stiffness, non-linear hysteresis, and friction affect the kinematic 
parameters of the gear transmission [14]. During the gear operation, an increase in stresses is accompanied by a temperature rise due to contact/lubrication-induced processes. The respective thermomechanical analysis of flexspline teeth rim of harmonic drive was reported in [15]. Harmonic drive design solution effect on the gear stiffness during the load application was studied in $[16,17]$. Depending on the number of working teeth, which are currently involved in the load transfer, the strain distribution in the flexspline is changing significantly [18]. Hence, it is expedient to analyze the sleeve (flexspline) design impact on the stress distribution during the torque load transfer.

As shown in Fig. 1, a harmonic drive consists of three main components: rigid circular spline (inner teeth), flexspline (external teeth), and wave generator. The rotation of the generator causes a radial deformation of the flexsline. Due to the mismatch in the number of gear teeth (usually equal to 2), the flexspline moves relative to the circular spline. For this type of gear transmission, two regions of teeth engagement are observed (in the major axis).
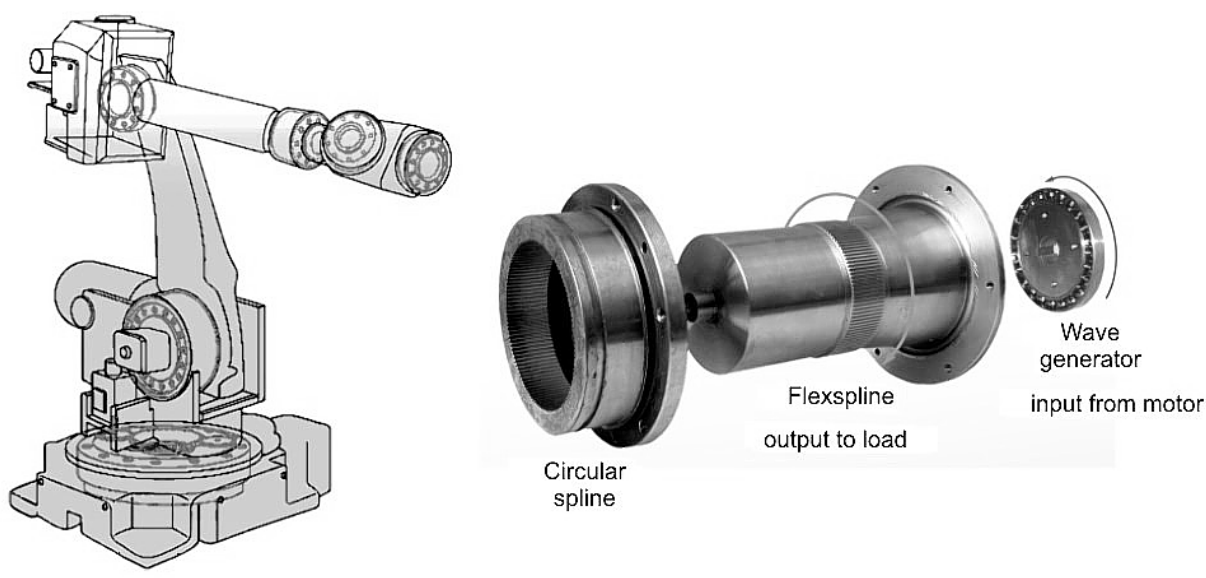

Fig. 1. Typical harmonic drive components.

In this paper, a mathematical model of shell component is reduced to the analysis of stress distribution due to the torque load application to a typical cam generator. Since the analytical determination of stresses for an assembly process involving complex parts is very difficult, the FEM analysis is performed for the zero torque load and the typical torque load value $T_{1}=150 \mathrm{~N} \cdot \mathrm{m}$. The numerical simulation allows one to assess the stress distribution and stress values in the specific areas of the flexspline. In numerical simulation, stress distributions were obtained for different types of wave generators: two-roller, four-roller, cam and disk ones. In the calculation of the stress distribution in the flexspline, contact elements between models were applied (generator was a master part and flexspline was a slave part). The proper deformation of the flexspline for each generator models was obtained by applying the generator radial displacement.

Sleeve Mechanical Shell Model. Stress analysis of a thin-walled cylindrical shell loaded by pressure was presented by Makhutov et al. [19]. However, in the case of application of additional rings (structural or stiffening walls), the model mathematical description becomes quite problematic, since the additional stiffening walls influence the thin-walled sleeve deformation. The experimental study of this problem was presented by Shektman [20].

In terms of the Kirchhoff-Love theory [21], the sleeve is described as a shell, with an ideal mechanical contact being applied between the shell and plate. The stresses in the cylindrical shell are derived as follows: 


$$
\begin{aligned}
& \sigma_{z}=\frac{1}{2 h}\left(N_{1 t}+3 \frac{\gamma}{h^{2}} M_{1 t}\right), \\
& \sigma_{\theta}=\frac{1}{2 h}\left(N_{2 t}+3 \frac{\gamma}{h^{2}} M_{2 t}\right), \\
& \sigma_{z \theta}=\frac{1}{2 h}\left(S_{12}+3 \frac{\gamma}{h^{2}} H_{12}\right),
\end{aligned}
$$

where $2 h$ is the shell thickness.

The equilibrium equations in displacements have the following form:

$$
\begin{gathered}
\frac{D_{0 t}}{1-v^{2}}\left[\frac{\partial^{2} u_{1}}{\partial z^{2}}+\frac{v}{R}\left(\frac{\partial^{2} u_{2}}{\partial z \partial \theta}+\frac{\partial w_{t}}{\partial z}\right)\right]-\frac{D_{0 t}}{2 R(1+v)}\left(\frac{\partial^{2} u_{1}}{\partial \theta^{2}}+\frac{\partial^{2} u_{2}}{\partial \theta \partial z}\right)=0, \\
\frac{1}{R} \frac{D_{0 t}}{\left(1-v^{2}\right)}\left[\frac{1}{R}\left(\frac{\partial^{2} u_{2}}{\partial \theta^{2}}+\frac{\partial w_{t}}{\partial \theta}\right)+v \frac{\partial^{2} u_{1}}{\partial \theta \partial z}\right]+\frac{D_{0 t}}{2(1+v)}\left(\frac{1}{R} \frac{\partial^{2} u_{1}}{\partial z \partial \theta}+\frac{\partial^{2} u_{2}}{\partial z^{2}}\right)- \\
-\frac{D_{1 t}}{R^{2}}\left[\frac{1}{R^{2}} \frac{\partial}{\partial \theta^{2}}\left(\frac{\partial w_{t}}{\partial \theta}-u_{2}\right)+v \frac{\partial^{3} w_{t}}{\partial \theta \partial z^{2}}\right]-\frac{2 D_{1 t}(1-v)}{R^{2}} \frac{\partial}{\partial z^{2}}\left(\frac{\partial w_{t}}{\partial \theta}-u_{2}\right)=0 \\
\frac{D_{0 t}}{1-v^{2}}\left(\frac{1}{R} \frac{\partial u_{2}}{\partial \theta}+\frac{w_{t}}{R}+v \frac{\partial u_{1}}{\partial z}\right)+D_{1 t} R\left[\frac{\partial^{4} w_{t}}{\partial z^{4}}+\frac{v}{R^{2}}\left(\frac{\partial^{4} w_{t}}{\partial z^{2} \partial \theta^{2}}-\frac{\partial^{3} u_{2}}{\partial z^{2} \partial \theta}\right)\right]+ \\
+\frac{2 D_{1 t}(1-v)}{R} \frac{\partial^{3}}{\partial \theta \partial z^{2}}\left(\frac{\partial w_{t}}{\partial \theta}-u_{2}\right)+\frac{D_{1 t}}{R}\left[\frac{1}{R^{2}} \frac{\partial^{3}}{\partial \theta^{3}}\left(\frac{\partial w_{t}}{\partial \theta}-u_{2}\right)+v \frac{\partial^{4} w_{t}}{\partial z^{2} \partial \theta^{2}}\right]= \\
=-D_{1 t}\left[\frac{1}{R^{2}} \frac{\partial^{2}}{\partial \theta^{2}}\left(\frac{\partial w_{t}}{\partial \theta}-u_{2}\right)+v \frac{\partial^{3} w_{t}}{\partial \theta \partial z^{2}}\right],
\end{gathered}
$$

where $D_{0 t}=2 E h$ and $D_{1 t}=\frac{2}{3} \frac{E h^{3}}{1-v^{2}}$ are tensile and bending stiffness values, respectively.

Taking into account the shell boundary conditions: $z=0$ to $w_{t}=w, M_{1 t}=0$, and $N_{1 t}=0 ; \quad z=1$ (an ideal mechanical contact with the plate), after integration and substitution of dimensionless values we get:

$$
\frac{d^{4} w_{0}}{d x^{4}}+4 w_{0}=0 .
$$

Thus, stresses in the shell are

$$
\begin{gathered}
\sigma_{z}=-\frac{3 D_{0 t} R \gamma d^{2} w_{0}}{8 a^{2} h^{3}}, \\
\sigma_{\theta}=\frac{1}{2 h}\left(N_{2 t}+3 M_{2 t} \frac{\gamma}{h^{2}}\right) .
\end{gathered}
$$


The maximum stresses at the shell external (+) and internal (-) surfaces for $\gamma= \pm h$ are calculated as follows:

$$
\begin{gathered}
\sigma_{z}^{ \pm}=\mp \frac{3 D_{0 t} R \gamma d^{2} w_{0}}{8 a^{2} h^{2} d x^{2}}, \\
\sigma_{\theta}^{ \pm}=\frac{D_{0 t} w_{0}}{2 h}+v \sigma_{z}^{ \pm} .
\end{gathered}
$$

The equilibrium equations for an annular plate (which corresponds to the bottom of flexspline teeth rim of harmonic drive) are

$$
\begin{gathered}
\frac{d^{2} u}{d r^{2}}+\frac{1}{r} \frac{d u}{d r}-\frac{u}{r^{2}}=0, \\
\frac{d^{3} w_{p}}{d r^{3}}+\frac{1}{r} \frac{d^{2} w_{p}}{d r^{2}}-\frac{1}{r^{2}} \frac{d w_{p}}{d r}=0 .
\end{gathered}
$$

The radial and circumferental stresses in the plate are, respectively:

$$
\begin{gathered}
\sigma_{r}=\frac{1}{2 h_{1}}\left(N_{1 p}+3 \frac{\gamma}{h_{1}^{2}} M_{1 p}\right), \\
\sigma_{\varphi}=\frac{1}{2 h_{1}}\left(N_{2 p}+3 \frac{\gamma}{h_{1}^{2}} M_{2 p}\right) .
\end{gathered}
$$

Thus, we get the following boundary conditions for a plate $\left(u=0, M_{1 p}=0, r=b\right)$; while $r=d$ corresponds to the ideal mechanical contact with the shell:

$$
u(d)=w_{t}(l), \quad \frac{d w_{p}(d)}{d r}=\frac{d w_{t}(l)}{d z}, \quad N_{1 p}(d)=Q(l), \quad M_{1 p}(d)=M_{1 t}(l) .
$$

Finally, the maximum stresses at the external (+) and internal (-) shell surfaces are reduced to

$$
\begin{gathered}
\sigma_{z}^{ \pm}= \pm \frac{3 E R}{a^{2} h}\left(A \cosh x \sin x-B \sinh x \cos x-\frac{w_{*}}{2 R} e^{-x} \sin x\right), \\
\sigma_{\theta}^{ \pm}=E\left(2 A \sinh x \cos x+2 B \cosh x \sin x+\frac{w_{*}}{2 R} e^{-x} \cos x\right)+v \sigma_{z}^{ \pm} .
\end{gathered}
$$

The maximum stresses at the external $(+)$ and internal $(-)$ plate surfaces are:

$$
\begin{aligned}
& \sigma_{r}^{ \pm}=\frac{E}{\left(1-v^{2}\right)}\left\{C_{1}\left[1+v+\frac{b^{2}}{r^{2}}(1-v)\right] \mp C_{3}\left(\frac{v-1}{r^{2}}+\frac{1-v}{b^{2}}\right)\right\}, \\
& \sigma_{\varphi}^{ \pm}=\frac{E}{\left(1-v^{2}\right)}\left\{C_{1}\left[1+v+\frac{b^{2}}{r^{2}}(v-1)\right] \mp C_{3}\left(\frac{1-v}{r^{2}}+\frac{1-v}{b^{2}}\right)\right\},
\end{aligned}
$$


where

$$
\begin{aligned}
& A=\frac{1}{L}[(n \psi-p s)(k \delta-t \xi)+(\alpha \xi+\lambda \delta)(p q-m n)], \\
& B=\frac{1}{L}[(n \psi-p s)(q \xi+m \delta)-(n k+p t)(\alpha \xi+\lambda \delta)], \\
& C_{1}=\frac{1}{n}(s-A t+B q), \quad C_{3}=\frac{1}{\delta}(A q+B t-\alpha), \\
& L=(p q-m n)(q \xi+m \delta)-(n k+p t)(k \delta-t \xi), \\
& k=2 \sinh \beta \cos \beta, \quad m=2 \cosh \beta \sin \beta, \quad q=2(\cosh \beta \cos \beta-\sinh \beta \sin \beta), \\
& t=2(\cosh \beta \cos \beta+\sinh \beta \sin \beta), \quad s=\frac{w_{*}}{R} e^{-\beta}(\cos \beta-\sin \beta), \\
& \alpha=\frac{W_{*}}{R} e^{-\beta}(\cos \beta+\sin \beta), \quad \psi=\frac{W_{*}}{R} e^{-\beta} \cos \beta, \quad \lambda=\frac{W_{*}}{R} e^{-\beta} \sin \beta, \\
& \xi=\frac{2 a^{2} h_{1}^{3}}{3\left(1-v^{2}\right) h R}\left(\frac{v-1}{d^{2}}+\frac{v-1}{b^{2}}\right), \quad p=\frac{1}{R}\left(d-\frac{b^{2}}{d}\right), \quad n=\frac{2 a^{2} h_{1}}{\left(1-v^{2}\right) h}\left[1+v-\frac{b^{2}(v-1)}{d^{2}}\right], \\
& x=\frac{a z}{R}, \quad a=\sqrt[4]{\frac{3\left(1-v^{2}\right) R^{2}}{4 h^{2}}}, \quad \delta=\frac{1}{a}\left[\frac{1}{d}+\frac{(1-v) d}{(1-v) b^{2}}\right], \quad \beta=\frac{a l}{R}, \quad 0 \leq z \leq l .
\end{aligned}
$$

\section{Experimental Methodology and Scope Research.}

FEM Methodology. Numerical simulation using 3D models is quite time-consuming due to the large number of finite elements. In view of the harmonic drive symmetry by the major and minor axes, the flexspline CAD model was designed for its half, which is symmetrical along the minor axis. The generator variant CAD models were constructed. The main goal was to study the effect of a wave generator design on the stress distribution in the flexspline teeth rim of harmonic drive. Hence, a simplified model of the gear teeth, with an unchanged shape of the remaining flexspline, was adopted. In the simplified model, teeth were replaced by a ring of $h_{n}$ thickness corresponding to the residual stress values of teeth. Based on the design calculations and the literature, the $K_{y}$ coefficient, which takes into account the residual stresses, was set at $K_{y}=0.7$. Hence, the total thickness of the ring was determined as $h_{n}=1.8 \mathrm{~mm}$. This simplification reduces the number of finite elements used for discretization of the flexspline-wave generator arrangement. In the numerical discretization process, hexahedral and contact elements were used.

In the FEM model, symmetrical deformation of the flexspline teeth rim was adopted for deformation by wave generator and for analysis with torque load applied. Hence, the 3D flexspline model for the calculation of stress distribution was used (Fig. 2). To simulate the true operation conditions of the harmonic drive, the respective boundary conditions were assumed. Nodes in the cross-sectional plane, indicated as $B$ in Fig. 2, were assumed to displace only in the $X Y$ plane, while the nodes of the flexspline flange (indicated as $D$ in Fig. 2) were fixed. The model's $Z$ axis corresponded to the major axis, and $X$ axis to the minor one of the wave generator. Thus, displacements of the wave generator model were allowed only in the plane perpendicular to the major axis (nodes indicated as $C$ in Fig. 2). 


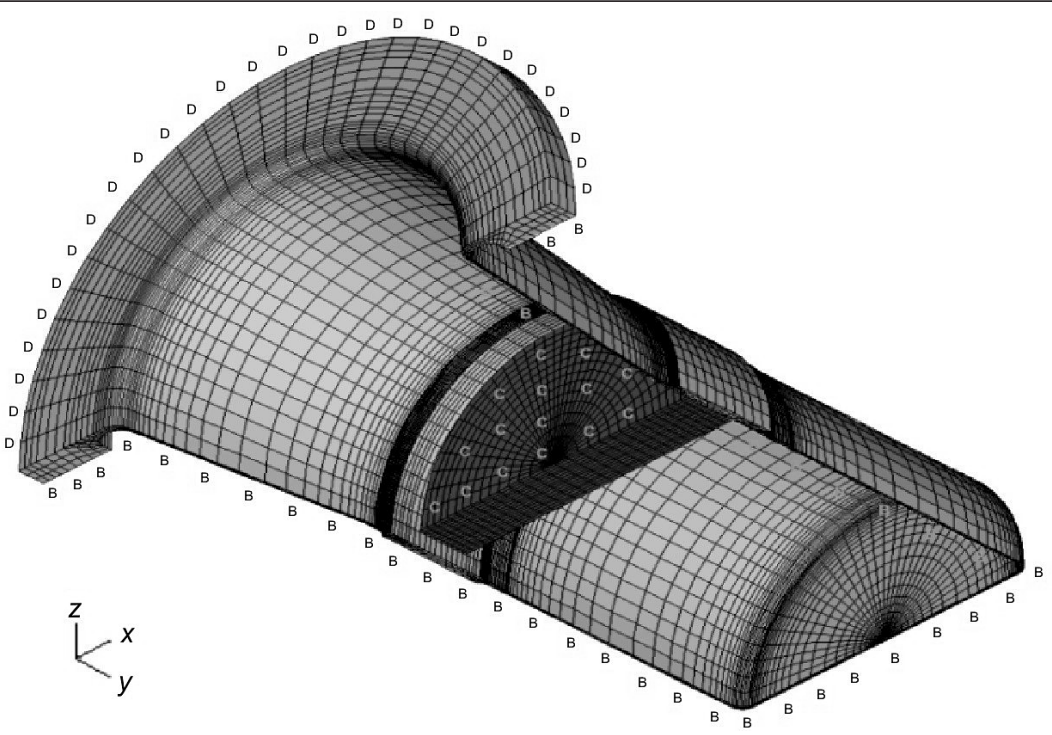

Fig. 2. Flexspline model used in FEM calculation.

To study the effect of the wave generators of different types on the stress distribution in the flexspline, the following models were constructed: two-roller, four-roller, cam, and disk ones. After the model discretization by using hexahedral elements, calculations of flexspline deformation for each wave generator model were performed. The wave generator models and torque load applying are presented in Fig. 3 in the form of teeth ring cross sections.

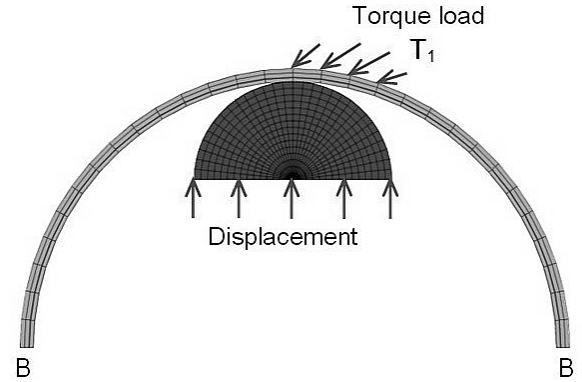

a

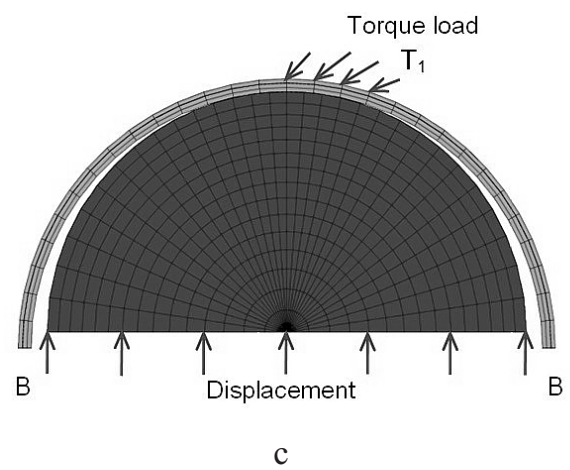

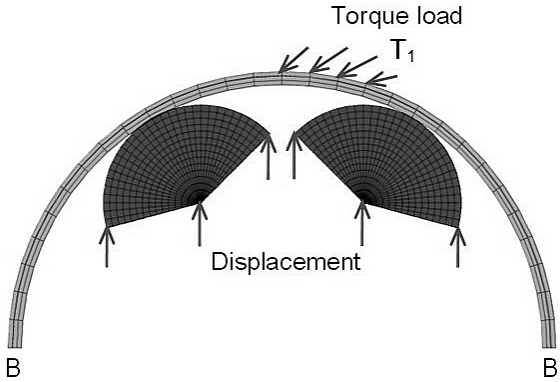

b

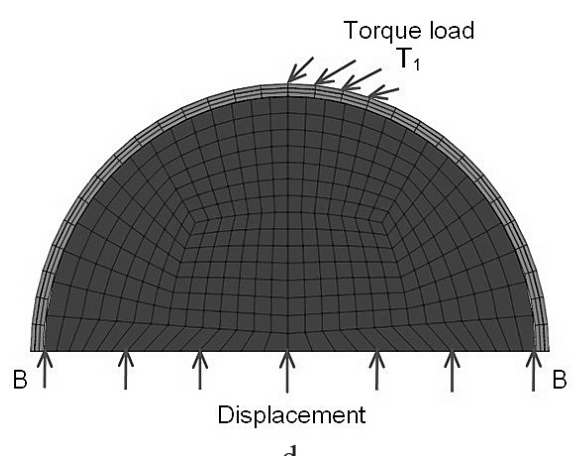

d

Fig. 3. Hermetic harmonic drive parts for stress analysis of flexspline teeth rim deformed by wave generator: (a) two-roller; (b) four-roller; (c) cam; (d) disk. 
The stress calculation were performed for two variants. At the first step of numerical analysis, the stress distribution in the flexspline teeth rim deformed by each wave generator was obtained. At the second step, the torque load $T_{1}=150 \mathrm{~N} \cdot \mathrm{m}$ was applied to the models, which corresponded to load value in the true operation conditions of the harmonic drive.

Stress Experimental Measurement. Stress distribution results from FEA were verified by the experimental data for the respective flexspline parts deformed by cam wave generator. In each cross section, the circumferential $\left(\sigma_{1}\right)$ and axial $\left(\sigma_{2}\right)$ stress distributions were compared for the harmonic drive loaded by torque load $T_{1}=150 \mathrm{~N} \cdot \mathrm{m}$. To ensure the same operation conditions for FEA and tests, the same geometry, dimensions, and torque loads were used.

For the strain measurements using the extensometer method, the flexspline was prepared for experimental tests: strain gauges were glued to the flexspline surface(Fig. 4a). For this purpose, theTF-1 strain gauges manufactured by Tenmex were adhered by the TB-1731 cyanoacrylate glue. To protect the strain gauges and soldering points against adverse environmental conditions and ensure their protection from mechanical damage, the Silten silicon and adhesive tape were used to cover these.

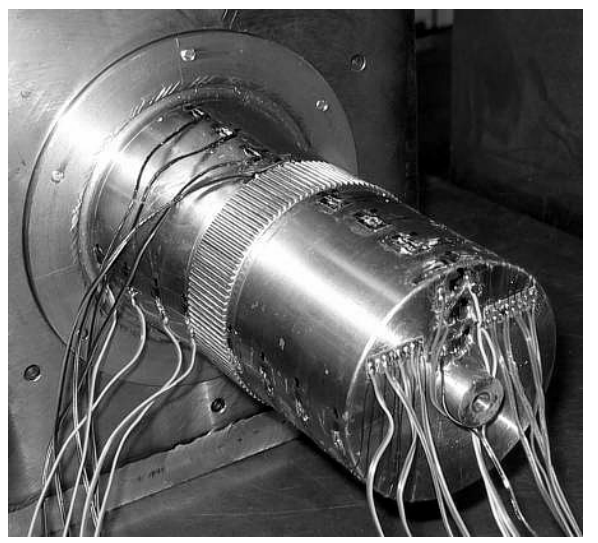

a
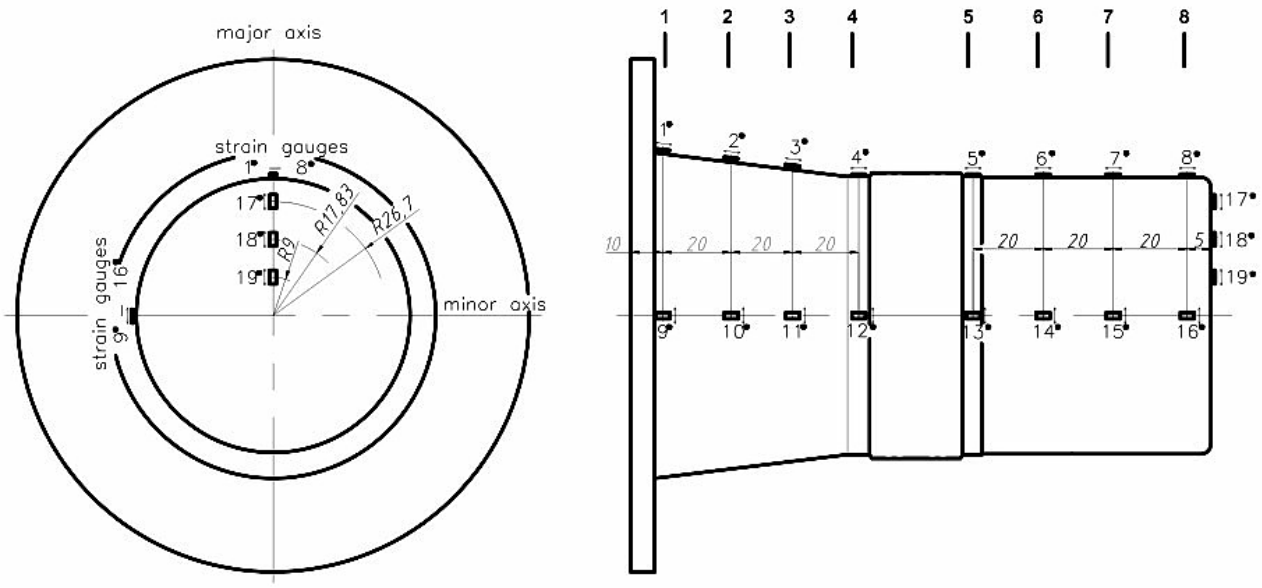

$\mathrm{b}$

Fig. 4. Flexspline teeth rim of the hermetic harmonic drive: (a) adhered foil strain gauges; (b) scheme of strain gauge' arrangement. 
In Fig. 4b, the arrangement of strain gauges in reference to the coordinate system are depicted. Assuming a zero angle for the plane of wave generator major axis, which divides the flexspline calculation model into two quarters, the one in the perpendicular plane with the minor axis is $90^{\circ}$. In the selected cross sections (Fig. 4b), the stress values were determined in two steps. The first measurement was performed for parallel plane to the model $Y$ axis, which corresponded to the direction of the axial stresses $\sigma_{2}$. The circumferential stresses $\sigma_{1}$ were measured in the plane, which was normal to the wave generator major axis. The experimental measurements were done only for the flexspline teeth rim deformed by the cam wave generator with the applied torque load $\left(T_{1}\right)$.

The positive stress values corresponded to the tensile load, and vice versa. The stress values obtained by the numerical simulation were assigned to the flexspline outer surface nodes so as to correspond to the respective cross section in the experimental measurements.

Results and Discussion. The differences in the stress distribution can be observed in the conical part of the flexspline tooth rim (Fig. 5). The maximum level of stresses $(700 \mathrm{MPa})$ on the teeth ring was observed in the roller-flexspline contact zone. For the two-roller wave generator, this zone was located in the major axis vicinity, while for the four-roller wave generator, the revealed zones with the maximum stress corresponded to the range of angles $\phi=25-30^{\circ}$ to the major axis. A high level of stresses was also obtained in all zones where the flexspline teeth rim changed it shape and in the teeth ring edges.

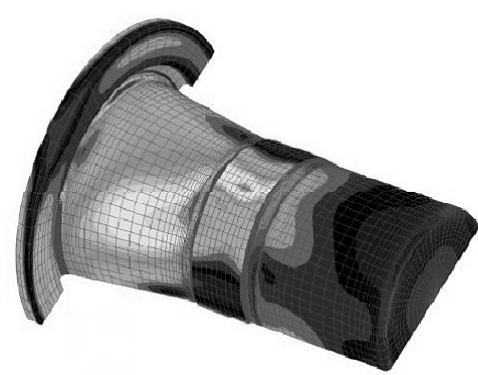

a

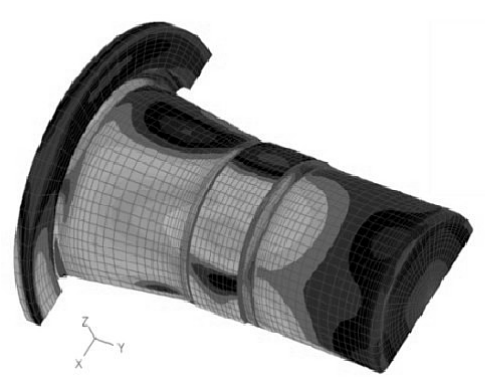

C

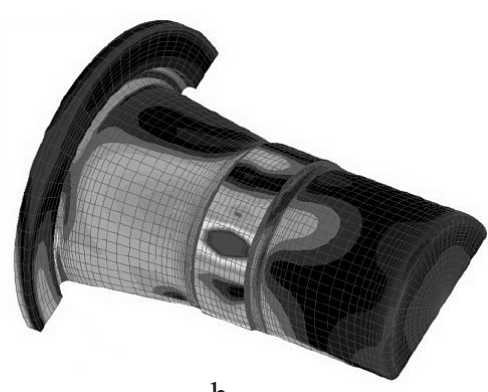

$\mathrm{b}$

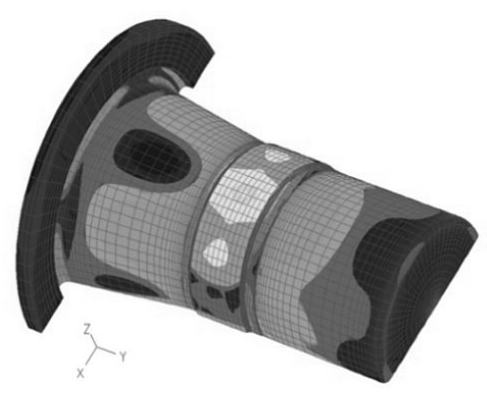

d

Fig. 5. Stress distribution in the flexspline teeth rim of hermetic harmonic drive deformed by wave generator $(150 \mathrm{~N} \cdot \mathrm{m}$ torque load): (a) two-roller; (b) four-roller; (c) cam; (d) disk.

The torque load caused a significant stress increase in the central zone of the flexspline conical part. The stress distribution changes were asymmetrical, because the stress increase was observed at the generator major axis, for which the torque load was applied, while for the opposite side of the generator major axis, the decreased stress level was observed. Such stress variation is not advantageous for the component operation, since it implies a significant deformation of the flexspline loaded with torque and thus, may aggravate the teeth heavy-load operational conditions. 
In case of a roller wave generator application, the stress distribution in the flexspline teeth rim is disadvantageous, and the stress level is high. The stress distribution in harmonic drives unloaded with torque load with cam and disk generators were very similar to each other. After applying the torque load the numerical model, the stress level slightly increased but the stress distribution did not change. This is due to the fact that the cam generator contacted with flexspline along the entire cam circumference, so the additional deformation under the torque load was blocked. Thus, application of a cam generator allows one to obtain the deformation, which would guarantee a proper operation of its teeth. For this generator, the maximum stress levels corresponding to the torque load were lower than those of any other generator types used in this study.

In the numerical model, the highest stress values of about 400 MPawere obtained in the first and fourth cross sections of the flexspline conical part (Fig. 6a). In cross section 4 (Fig. 4b), which was located close to the gear teeth in the major axis $\left(90^{\circ}\right)$, the tensile stresses were obtained, while in the minor axis plane the compressive ones were obtained. And for cross section 1 located close to the flexspline flange, the compressive stresses occurred in the major axis plane, and tensile ones in the minor one. In two other cross sections located close to the center of the conical part, the stresses directed along $Y$ axis were significantly lower and did not exceed $100 \mathrm{MPa}$. The stress values in the cylindrical part (Fig. 6b) co-directed with the flexspline axis were lower than those in the conical part (Fig. 6a), and approached $300 \mathrm{MPa}$. The highest values were observed in cross section 5 , which was located close to the gear teeth, and their values decreased with the distance from from gear teeth.

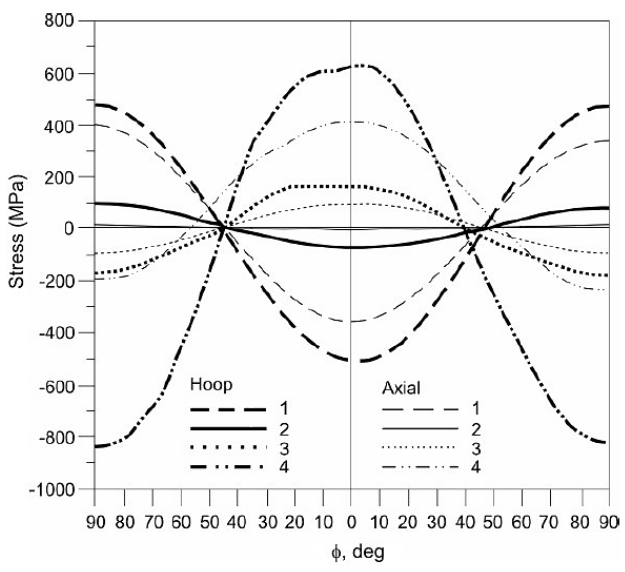

a

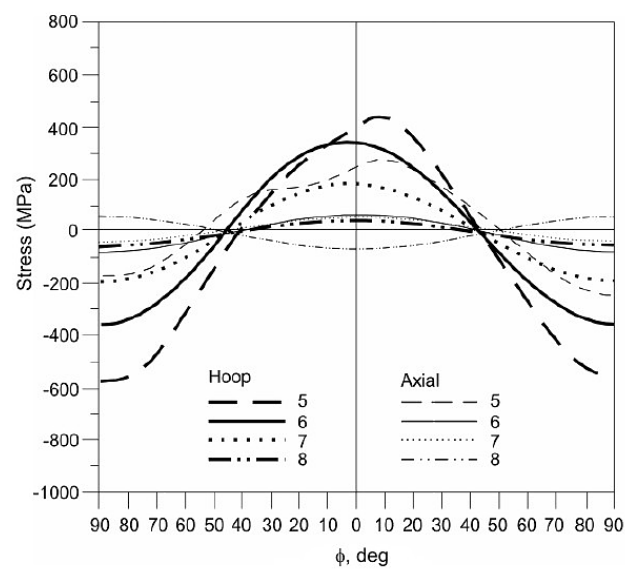

b

Fig. 6. Axial and circumferential stresses in flexspline teeth rim of hermetic harmonic drive deformed by cam wave generator at the torque load of $150 \mathrm{~N} \cdot \mathrm{m}$.

For the same flexspline model in $1-8$ cross sections perpendicular to the major axis, the circumferential stresses were measured (Fig. 6). For the first four of analyzed cross sections, the highest stress values exceeding $800 \mathrm{MPa}$ were obtained in cross section located close to the gear teeth (Fig. 6a). In the flange area (cross section 1), the stress level was also high (400 MPa) in the major and minor axes' zones. For both axial stresses and circumferential stresses, the specific stress distribution due to the applied torque load $\left(T_{1}\right)$ was observed (Fig. 6a). In the cross section closest to the gear teeth, the highest stress value was observed in the major axis plane $\left(\phi=0^{\circ}\right)$.

In case of axial stresses in the conical part, a good agreement of the experimental and numerical simulation results was obtained (Fig. 7a). The waveforms were similar to each 
other, although small differences in the stress value were obtained. The above differences may be attributed to both limited FEM accuracy and limited possibilities of strain measurement via strain gauges. Moreover, the axial stresses in cross section 4 (from -90 to $-70^{\circ}$ and from 90 to $70^{\circ}$ ) have a different waveform, see Fig. 8a. The reason of this difference may be that cross section 4 is located close to the point of the flexspline shape variation (from conical to cylindrical part).

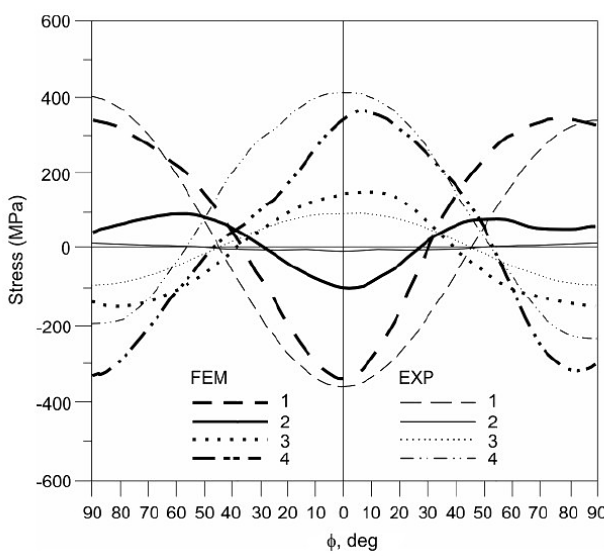

a

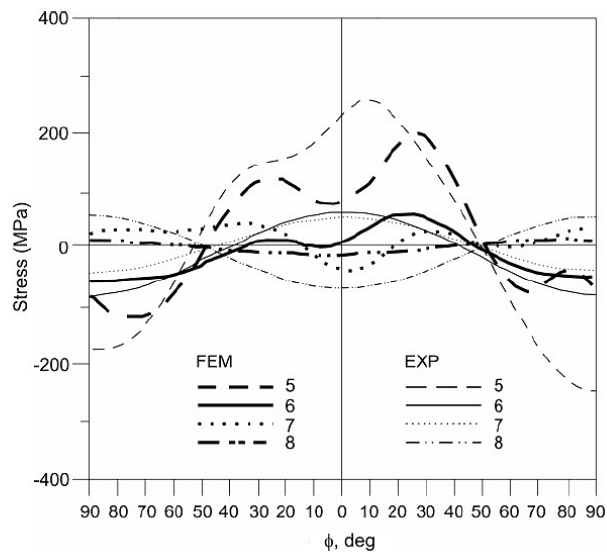

b

Fig. 7. Axial stresses in specified cross sections according to the rotation angle for conical (a) and cylindrical (b) parts.

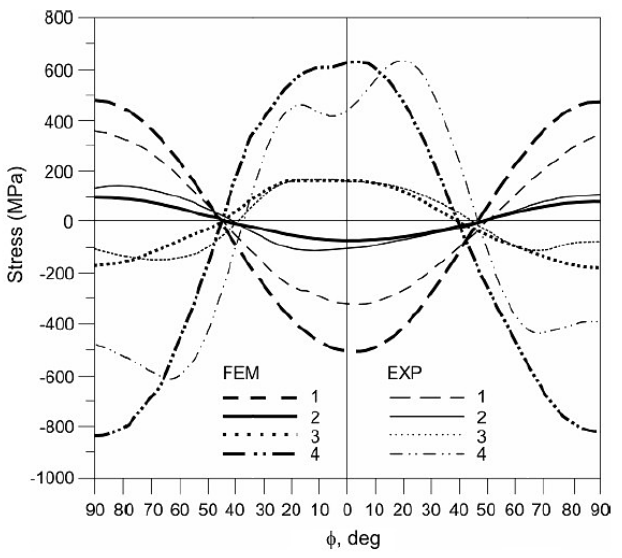

a

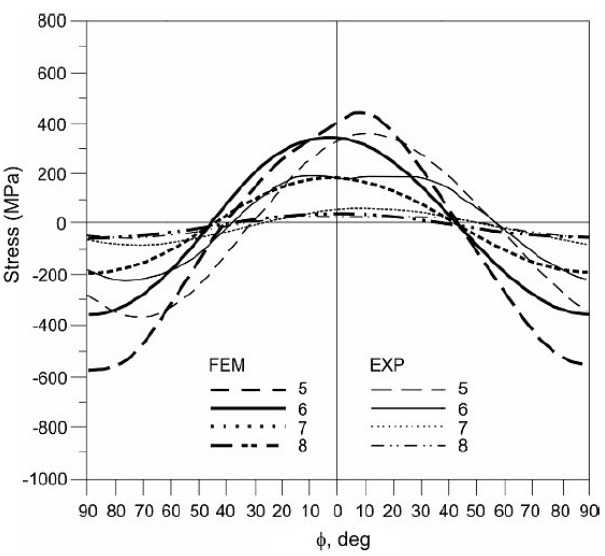

b

Fig. 8. Circumferential stresses in specified cross sections according to the rotation angle for conical (a) and cylindrical (b) parts.

Verification of the results obtained for the cylindrical part of the flexspline teeth rim revealed smaller differences in the stress distribution. In case of cross sections in the cylindrical part of the flexspline, the agreement of esperimental and numerical results was the highest (Fig. 8b), due a simple geometry and better measurement conditions for such shapes. The tension-rotation angle characteristics were slightly different for stresses in cross sections 5 and 6 (Fig. $7 \mathrm{~b}$ ), which may be attributed to the flexspline shape variation effect on the stress distribution in these cross sections. The computational specifics could 
also ensure the above differences: the stress distribution was measured in the mesh nodes, which made it possible to use more measurement points than in previous cases.

Conclusions. Knowledge of the stress distribution in the flexspline teeth rim of hermetic harmonic drive makes possible the most appropriate selection of a wave generator for reducing the stress level, especially in the place of shape geometry variation.

The use of a cam generator yields the most adequate (i.e., the most accurately controlled) deformation among the analyzed generators types, which would guarantee the optimal teeth engagement of flexspline and circular spline.

After applying the torque load to the numerical models, a sharp change in the stress distribution was observed for the roller and disc wave generators. In the zones with a high level of stresses, the stress values increased by approximately $30 \%$ after applying the torque load.

A high level of stresses was also observed in all zones where the flexspline teeth rim changed it shape, as well as in the teeth ring edges. In respective cross sections, the maximum stress values were co-directed with the major and minor axis of the flexspline teeth rim.

The application of experimental stress/strain measurements via strain gauges to to the verification of numerical simulation results was found to have its test limitations. However, successful stress measurements in the particular cross sections of the flexspline teeth rim were obtained in this work. A feasibility of the proposed numerical model was verified by the test results.

\section{Р е 3 юм е}

Проведен численный расчет напряжений в гибком сплайне зубчатой передачи гармонического (волнового) редуктора. Зубчатое кольцо в гибком сплайне из-за сложной геометрии моделировалось в виде кольца. Высоту кольца принимали с учетом напряженности в зубьях. Для изучения влияния различных типов волновых генераторов на распределение напряжений в гибком сплайне рассматривали модели с двумя и четырьмя роликами, эксцентриком и диском. Расчет напряжений выполняли для двух вариантов: без вращающего момента и с вращающим моментом, соответствующим реальным условиям работы герметического гармонического редуктора.

1. T. Markowski, J. Mucha, and Witkowski W., "FEM analysis of clinching joint machine's C-frame rigidity," Eksploatacja i Niezawodnosc - Maintenance and Reliability, 15, No. 1, 51-57 (2013).

2. M. Hać and W. Ostapski, "Dynamics of planar manipulators with flexible links driven by motors with harmonic drives," Mach. Dyn. Probl., 22, 19-31 (1998).

3. T. Tjahjowidodo, F. Al-Bender, and H. Van Brussel, "Theoretical modelling and experimental identification of nonlinear torsional behaviour in harmonic drives," Mechatronics, 23, No. 5, 497-504 (2013).

4. H. Dong, K-L. Ting, and D. Wang, "Kinematic fundamentals of planar harmonic drives,” J. Mech. Design, 133, No. 1, 011007 (2011), DOI:10.1115/1.4003140.

5. Z. Chao, W. Shaoping, W. Zimeng, and W. Xingjian, "An accelerated life test model for harmonic drives under a segmental stress history and its parameter optimization," Chinese J. Aeronaut., 28, No. 6, 1758-1765 (2015).

6. T. Markowski, J. Mucha, and W. Witkowski, "Automating the modelling process of involute spur gears with straight teeth," Adv. Sci. Technol. Res. J., 7, No. 19, 66-69 (2013). 
7. T. Hidaka, T. Ishida, Y. Zhang, et al., "Vibration of a strain-wave gearing in an industrial robot," in: Proc. of the Int. Power Transmission and Gearing Conf. (1990), pp. 789-794.

8. R. Bogacz and S. Noga, "Free transverse vibration analysis of a toothed gear," Arch. Appl. Mech., 82, 1159-1168 (2012).

9. T. Marilier and J.A. Richard, "Non-linear mechanic and electric behavior of a robot axis with a "harmonic-drive" gear," Robot. Comput. Integr. Manuf., 5, Nos. 2-3, 129-136 (1989).

10. D. P. Volkov and Y. N. Zubkov, "Vibration in a drive with harmonic gear transmission," Russ. Eng. J., 58, No. 5, 17-21 (1978).

11. C. Preissner, T. J. Royston, and D. Shu, "A high-fidelity harmonic drive model," J. Dyn. Syst. Meas. Control., 134, No. 1, 011002, DOI:10.1115/1.4005041.

12. Y. Fan, H. Wang, and D. Song, "Kinematics computerized simulation for conjugate tooth profiles of harmonic drive," J. Nanjing Univ. Sci. Technol., 34, No. 5, 448-450 (2002).

13. O. Kayabasi and F. Erzincanl, "Shape optimization of tooth profile of a flexspline for a harmonic drive by finite element modeling," Mater. Design, 28, No. 2, 441-447 (2007).

14. N. Kircanski, A. A. Goldenberg, and S. Jia, "An experimental study of nonlinear stiffness, hysteresis, and friction effects in robot joints with harmonic drives and torque sensors," in: T. Yoshikawa, F. Miyazaki (Eds.), Lecture Notes in Control and Information Sciences, Vol. 200, LNCIS (1993), pp. 326-340.

15. L. Liu, B. You, P. Wang, et al., "Heat-structure coupling analysis of harmonic drive under different thermal loading," Int. J. Control Autom., 11, 201-2010 (2015).

16. P. Folega and G. Siwiec, "Numerical analysis of selected materials for flexsplines," Arch. Metall. Mater., 1, 185-191 (2011).

17. H. Gao, H. Zhuang, Z. Li, et al., "Optimization and experimental research on a new-type short cylindrical cup-shaped harmonic reducer," J. Cent. South Univ., 19, 1869-1882 (2012).

18. Y. S. Hareesh and J. Varghese, "Design and analysis of flex spline with involute teeth profile for harmonic drive mechanism," Int. J. Eng. Res. Technol., 4, No. 12, 613-618 (2015).

19. N. A. Makhutov, L. I. Gladshtein, and Yu. M. Grachev, "Failure of models of thin-walled shells when loaded by internal pressure," Strength Mater., 8, No. 2, 123-129 (1976).

20. Yu. V. Shektman, "Experimental investigation of the stability of cylindrical shells with stiffening rings, under the action of external pressure," Strength Mater., 1, No. 6, 650-655 (1969).

21. S. Timoshenko and S. Woinowsky-Krieger, Theory of Plates and Shells, McGrawHill Book Company (1959). 